\title{
Implementation of Economic Rights Principles on Trademark In Trading of Product in The Pandemic Covid-19 Era
}

\section{Delfiyanti}

Faculty of Law Andalas University, Padang, Indonesia E-mail:delfiyanti@law.unand.acid

\begin{tabular}{l}
\hline Article Info \\
\hline Keywords: \\
Development; \\
Economic Right \\
Principle; Trademark \\
and Covid-19 \\
Pandemic Era. \\
\\
\\
DOI: \\
\hline
\end{tabular}

Abstract
In accompany with the tight trading competition, it is imply that trademark
plays significant role to known as the special product in common and had
the power and useful when it managed in appropriate. Trademark is not
just the word related to the product or collection only but the process and
business strategy. Therefore, trademark have a value and equity. Thus
equity becomes important as the value to be a benchmark of product in the
marketplace. However, the pandemic of Covid-19 that struck since
beginning of 2020 had an enormous impact to the whole states in the world
including Indonesia. The pandemic was bring worst influences to the
economic and trading. The deadly disease automatically was paralyze an
economy and trading. It is caused by restriction of people to drive and
influences the product movement. Temporarily, export-import activities
delayed as restriction of transportation entry among the states. Finally,
Indonesia forced close for in and out flight of territory. The situation
influence to the implementation of Economic Right of trademark right
attach to the import and export products in Indonesia.

\section{A. INTRODUCTION}

Indonesia, which is a member of the Asean Economic Community (MEA), has become a risk in competition in the economic field, especially Intellectual Property which is developing in the flow of the Asean Economic Community (AEC) as the main pillar in the economic development of a country ${ }^{1}$. As an intellectual product, trademark play an important role for continuity and increases good and service transaction of trading and investment ${ }^{2}$. Trademark with the image can accomplish the customer demand for the important sign or distinguish and guarantee for good and service qualities in the competition atmosphere. Therefore, trademark is en aconomic asset to the owner, individual or collective (corporation) that will bring a huge benefit. For importance, it is attached legal protection to the brand, an object in correlation with individual or corporation rights. ${ }^{3}$ The decision based trademark protection including protection

1 Labetubun, M. A. H., Akyuwen, R. J., \& Pariela, M. V. G. (2018). Perlindungan Pengetahuan Tradisional secara Sui Generis untuk Menyongsong Masyarakat Ekonomi Asean. Sasi, 24(1), 1-10.

2 Labetubun, M. A. H., Pariela, M. V. G. (2020). Controlling of Imported or Exported Goods Related to Brand Protection By Customs, UNTAG Law Review, 4(1), 20-33, https://doi.org/10.36356/ulrev.v4i1.1522.

3 Sutedi, A. (2009). Intellectual Property Rights. Jakarta: Sinar Grafika, p. 91.

409|SASI Volume 27 Issue 4, October-December 2021 
against piracy has become a concern in both countries and the world. Initially, thiscase viewed bycounterfeiting-based problems.

Currently, The use of recognized trademark has flourish, this is because promising benefits when using it rather than own brands. Especially, inextended economic crisis such as present, many producers have come up by combining an original branded product with pirated ones, as physically it similar to the original. There are many reasons why industries use recognizedbrands for the products easy to sell, besides it don't have to registration at the Director General of Intelectual Property Rihgts or spend a lot of money to build the image of products. They don't have to establishsa research and development division to produce an up to date product, justcopies other products and in marketing the "dealers" ready to accept for it.

Economically, use thefamous brands brings considerable profits and it proven, moreover it also supported by the purchasing power of mediocre consumers who want to appear trendy. Bythe legal aspect, it is unacceptableas Indonesia has ratified the International Convention on TRIPs and the WTO which was promulgated in Act No.7 of 1994 in accordance with the international agreement that on January 1st 2000 Indonesia had to implement all the agreements in TRIPs (Trade Related Aspects of Intellectual Property Right, Including Trade in Counterfeit Good), as the implementation of all the provisions is a consequence of the member of the WTO (Word Trade Organization). It is irrefutable that in current trading, trademark is a human intellectual property form which has decisive role due to the use in organization, however, it is also comprisesany legal aspects for owner, brand holderor public as userof goods or services of certain brands.

Trademark plays an important role for continuity and increases good and service transaction of trading and investment. Trademark with the image can accomplish the customer demand for the important sign or distinguish and guarantee for good and service qualities as it a kind of "initial seller" of product for consumers. In the competition era, the products entry from abroad to Indonesia cannot be restricted because the phenomenon has been predicted by Kanichi Ohmae, "that in the future the world cannot be restricted by anything" and it is to be true. As the asset trademark will be able to generate large profits when utilized by consideringa business aspects and good management. By increasing importance of role of trademark, it is necessary to put the legal protection on a trademark, namely as an object related to the rights of individuals or legal entities, for this reason, legal certainty over the right to a mark is a registration of a mark to obtain legal protection which can be proven by a trademark certificate. ${ }^{4}$

Actually, the top brand preceded by a reputation and good will as usual that is attached to the fame. The high "good will" brand be able to provide extraordinary benefits to the company, even though is actually intangible. It will be transformed into a capital asset based solely on good will; according to Lendsford, it is stated that a company with high reputation brand will have extraordinary wealth assets based solely on the good will of brand.

Branded good or services are advertised and sold beforehand with each other, albeit the good or service is not available physically in particular market. Modern dissemination and advertising media are becoming increasingly unrestricted by boundaries given the sophistication of communication technology and the frequency when the people travel across the globe. The owner of a branded good or service takes advantage of various events that many people watching it to tradethe product to make them put an interestfor products or using the advertised services.

By the legal aspect, trademark becomesan important matter, in connection with legal

${ }^{4}$ Labetubun, M. A. H., "The Legal Review of The Rights of Foreign Brands Onweaknesses of First To Fole Registration Principles In Indonesia," in International Conference: Intellectual Property and Potential Resources for Public Welfare (Mataram: Faculty of Law, University of Mataram in Cooperation with Association of Intellectual Property Lecturer of Indonesia, 2017), 213-27.

410|S ASI Volume 27 Issue 4, October-December 2021 
protection requirement and legal certainty for trademark owners or holders and public as consumers of goods or services that use the brand in avoida misleading by other brands; it cannot be denied that using of well-known brandmatter by unauthorized parties is familiar in Indonesia and it is recognized by the government, but many obstacles in practice.

As we known that main purpose of business is profit;but the industries do not understand the importance of the relationship between entrepreneurs, consumers and society considersthe "profit oriented" without respect to other aspects and again concerned only to their own interests regardless the interests of other parties and what encourages them to do more the availability of consumers who use their products.

The different perceptions in society on brands leads to various interpretations, however it does not means that people who produce an item by using the fame of others be justified, because allowing irresponsible actions indirectly produces and justifying someone to cheat and enrich themselves dishonestly. Using a recognized brand of another, comprehensively, is not only detriment to the owner or brand holder and consumers, but the national economy and also harms international economic relations.

By the reasons, the most important problemis related to the implementation of the economic rights principle in the trademark rights attached to the trading products. The great economic value of the brands has made companies try to maintain the quality of these goods. Especially to theexport and imported goods, the quality is very much taken into account to get theeconomic value. However, the Corona-19 virus pandemic which has plagued almost all countries since the beginning of 2020 has had a considerable impact on countries in the world, including Indonesia. The pandemic has a depth impact on economy and trading. During the situation, the economy was automatically paralyzed and trade did not proceed as usual. It is caused byrestricted space for people moving andinfluence to the goods movement. Exportimport are delayed due to restriction of transportation enter to the region. Indonesia, eventually closed the flights from any countriesinto the territory. It also results in the implementation of the Economic Rights principles on trademark rights that attached to export and imported goods in Indonesia.

\section{B. RESULTS AND DISCUSSION}

Based on Article 2 paragraph (2) the Act of Trademark No.20 of 2016, brands are divided into good and servicebrands. A good brand used on goods traded by a individual or persons collectively or a legal entity to distinguish it from other similar one. Furthermore, the brand right are attainedsince the mark registered. ${ }^{5}$ A registered trademark will have a trademark certificate that is officially issued by the Ministry of Law and Human Rights thusit is legally protected. Moreover, the trademark is registered, the owner will receive economic rights on it. The economic rights for the a trademark related to the commercialization when it is traded both nationally and internationally so that the owner or the holder has the exclusive right to use the trademark in the market and prohibits other parties for using it. Also, trademark relates to the reputation of the goods being traded thus there is no mistaking on well-known and highreputation brand that usually has high quality and price. Generally, society as a consumer will choose a product by identifying the label of the product.

It also will bring atight competition between products in market place. Manufacturers attempt to improve of sales of goods, by making a good and attractive reputation for product. However, also there are manufacturers against the law by imitating other products or claiming ownership of the trademark from the other. It is becomes an interesting challenge in attempt to maintain the identity and ownership of the trademark.

The Covid-19 pandemic era in early 2020 globally has changes the international

${ }^{5}$ Article 3 of Act No. 20 of 2016 on Trademark and Geographical Indications.

411|SASI Volume 27 Issue 4, October-December 2021 
community, including Indonesia in relation to the economy and trading ${ }^{6}$. The Restrictionin movement of both people and goods has bring worst impact to the buying and selling power in society. Especially for export and imported goods; before the Covid-19 pandemic trade in goods in and out of a country was running rapidly, but currently it all decline. At present, trade has had a wide impact as reduced purchasing power of the people both international and nationally.

Similarly, the impact of the Covid-19 on the world economy was devastating ${ }^{7}$. In the first quarter of 2020 economic ratein trading partner of Indonesia grew negatively: Singapore -2.2, Hong Kong -8.9, European Union -2.7 and China decline to minus 6.8. Several countries still grew positively but decreased compared to the previous quarter. The United States fell from 2.3 to 0.3 , South Korea from 2.3 to 1.3 and Vietnam from 6.8 to 3.8. Indonesia experienced a deep contraction from 4.97 in the fourth quarter of 2019 to only 2.97 in the first quarter of $2020 .^{8}$ Then, the report of the Central Statistics Agency (BPS) in August stated that Indonesia's economic growth in the second quarter of 2020 was minus 5.32 percent. Previously, in the first quarter of 2020, BPS reported that Indonesia's economic growth only grew by 2.97 percent, down considerably from the growth of 5.02 percent in the same period in $2019 .{ }^{9}$

The weakening economic situation evenly throughout all countries has affected global trade in goods. However, there are other parties who take advantage personally. They are goods brand with good reputation and will always exist and are bought by the public. It is encourages certain parties to produce goods by imitating well-known and established trademark so that the goods are sold and bought. However, it is difficult in current conditions to introduce a new trademark to society amid a weak economic situation so that most recognized trademark will be better able to survive amid the economic downturn of pandemic era.

The situationresult in violation of trademark ownership when a product is given a label from a previously brand so that a lawsuit can be filed. An interested party may file a lawsuit for the cancellation of a registered trademark and the cancellation submitted to the Commercial Court against the owner of the registered trademark. This is regulated in Article 83 of the Trademark Law; that the owner of a registered brand and/or licensee of a registered trademark can file a lawsuit against other parties who unlawfully use the trademark that has the same substantially or in its entirety for similar goods and/or services in the form of: a. claim for damages; and/or b. termination of all actions related to the use of the trademark. A lawsuit as referred to in may also be filed by a well-known brand owner based on a court decision that was submitted to the Commercial Court.

Moreover, violation of the trademark may also be subject to criminal sanctions as depictedon Article 100 paragraph (1) of the Trademark Law, that any person without the right to use a trademark that is the same as a registered trademark owned by another party for goods and or similar services produced and/or being traded, shall be punished with imprisonment of up to 5 (five) years from/or a maximum fine of Rp.2,000,000,000.00 (two billion rupiah). Article 100 paragraph (2) adds that every person without the right to use a trademark which is similar in essence to a registered trademark belonging to another party for similar goods and/or services produced and/or traded, shall be punished with imprisonment of a maximum of 4 (four) years and/or a maximum fine of IDR 2,000,000,000.00 (two billion rupiah).

By these legal provisions, users of goods brands must really understand of their action

6 Saija, R., \& Sudiarawan, K. A. (2021). Perlindungan Hukum Bagi Perusahaan Debitur Pailit dalam Menghadapi Pandemi Covid 19. Batulis Civil Law Review, 2(1), 66-77.

7 Kunarso, K., \& Sumaryanto, A. D. (2020). Eksistensi Perjanjian Ditengah Pandemi Covid-19. Batulis Civil Law Review, 1(1), 33-46.

8 Indonesia Economic Pasca Covid -19 Pandemic, Kompas, accessed on July 14, 2021.

9 Jawahir Gustav Rizal, Covid-19 Pandemic, How Impact for Labour Sector In Indonesia?, Kompas, accessed on July 16, 2021. 
consequency. The existence of exclusive economic rights to trademark owners and trademark rights holders in order to respect and protect the goods they have produced and to work hard so that their trademark can be accepted by the community. By the existence of legal provisions to encourage the economy and trade running fairly and transparently so that it will further improve the global economy.

\section{CONCLUSION}

A trademark is a human intellectual property with decisive role as the use of trademark in a company and also contains comprehensive legal aspects, both for the owner or holder of brand as well as to the consumer. The Covid-19 pandemic era at the beginning of 2020 has changes the international community globally including Indonesia in relation to the economy and trading. The restriction on movement of both people and goods has affected the buying and selling power. Especially, to the export and imported goods; before pandemic it is running in proper and in-out trading was rapidly but currently it is experiencing a decline. The existence of weakening economic conditions evenly throughout all countries was influences the global trading. However, there are other parties who take advantage of the situation personally. There are goods that have a brand with good reputation and will always exist and are bought by the public. It is encourages certain parties to produce goods by imitating well-known and established brands so that the goods are sold and bought. Therefore, the existence of various international and national arrangements is very important. Indonesia has made arrangements related to trademarks through Act No. 20 of 2016. The law provides regulation and protection related to trademarks.

\section{REFERENCES}

\section{Journal}

[1] Kunarso, K., \& Sumaryanto, A. D. (2020). Eksistensi Perjanjian Ditengah Pandemi Covid19. Batulis Civil Law Review, 1(1), 33-46.

[2] Labetubun, M. A. H., Akyuwen, R. J., \& Pariela, M. V. G. (2018). Perlindungan Pengetahuan Tradisional secara Sui Generis untuk Menyongsong Masyarakat Ekonomi Asean. Sasi, 24(1), 1-10.

[3] Labetubun, M. A. H., Pariela, M. V. G. (2020). Controlling of Imported or Exported Goods Related to Brand Protection By Customs, UNTAG Law Review, 4(1), 20-33, https://doi.org/10.36356/ulrev.v4i1.1522.

[4] Saija, R., \& Sudiarawan, K. A. (2021). Perlindungan Hukum Bagi Perusahaan Debitur Pailit dalam Menghadapi Pandemi Covid 19. Batulis Civil Law Review, 2(1), 66-77.

\section{Books}

[5] Sutedi, A. (2009). Intellectual Property Rights. Jakarta: Sinar Grafika.

\section{Online/World Wide Web, Thesis etc}

[6] Indonesia Economic Pasca Covid -19 Pandemic, Kompas.

[7] Jawahir Gustav Rizal, Covid-19 Pandemic, How Impact for Labour Sector In Indonesia?, Kompas.

[8] Labetubun, M. A. H., "The Legal Review of The Rights of Foreign Brands Onweaknesses of First To Fole Registration Principles In Indonesia," in International Conference: Intellectual Property and Potential Resources for Public Welfare (Mataram: Faculty of Law, University of Mataram in Cooperation with Association of Intellectual Property Lecturer of Indonesia, 2017), 213-27. 